\title{
Change in Properties of Bitumen Used for Road Construction in Bitumineral Mixtures
}

\author{
K.G. Pugin ${ }^{1,2, a^{*}}$, O.V. Yakontseva ${ }^{2, b}$, V.K. Salakhova ${ }^{2, c}$ and \\ K. Yu. Tyuryukhanove,d \\ ${ }^{1}$ Perm State Agro-Technological University named after Academician D.N. Pryanishnikov, Perm, \\ Russian Federation \\ 2Perm National Research Polytechnic University, Perm, Russian Federation \\ a123zzz@rambler.ru, byakontseva.olga@yandex.ru, cveronika815@inbox.ru, \\ duruchanov.k.u@list.ru
}

\begin{abstract}
Keywords: Bitumen, Asphalt Concrete, Bitumen Aging, Crushed Stone, Mineral Aggregate
\end{abstract}

\begin{abstract}
Premature destruction of asphalt concrete can be caused by the aging of bitumen, which is associated with a change in the physical and chemical properties of bitumen. The article shows that in most cases, the improvement of the characteristics of asphalt concrete is achieved through the introduction of additives that affect the basic properties of the bituminous binder, such as penetration, softening temperature, viscosity. The influence of the chemical composition of the mineral filler on the rate of bitumen aging has been experimentally proved. The obtained research data show that the increase in the rate of aging of bitumen is influenced by the compounds of silicon and aluminum. On the other hand, metals such as iron and titanium contribute to the preservation of the initial plasticity of bitumen, and the accumulation of asphaltenes in the structure of the bitumen-mineral mixture slows down.
\end{abstract}

\section{Introduction}

Currently, asphalt concrete remains the most common material for road construction. The construction of a modern transport infrastructure requires a large amount of asphalt concrete with increased performance indicators. This is due to an increase in the load on the pavement structure and the requirement to increase the operating time of the pavement before major repairs, to reduce the cost of work and used road materials, including asphalt concrete. Currently developed new technologies for producing asphalt concrete make it possible to obtain asphalt concrete with higher performance, but they imply the use of expensive polymer or composite materials, new technological equipment, expensive raw materials in the compositions and are not always feasible due to the climatic features of the construction area. [1-7] This leads to a significant rise in the cost of road construction. Premature destruction of asphalt concrete (wear, destruction of the surface layer of the road surface) can be caused by the aging of bitumen, which is associated with a change in the physical and chemical properties of bitumen. [8-10] The aging process of bitumen can occur during the preparation of an asphalt mixture at high temperatures or during operation asphalt concrete. The last aging process is of great importance for the initial physical and mechanical properties of bitumen, the presence of polymer and stabilizing additives in the asphalt concrete mixture, and the chemical composition of stone materials used as coarse and fine aggregates. [1113] Analysis of scientific literature showed that the chemical composition of stone materials used in the composition is not fully taken into account when choosing raw materials for the production of asphalt concrete. As a rule, the content of silicon oxides in the composition of the rock is taken 
into account, which determines the adhesion of bitumen to the surface of stone materials. [14-17] There are practically no studies on the effect of other chemical elements on the physicalmechanical, technological and operational properties of asphalt concrete. The relevance of such studies is due to the need to use local rocks for road construction, which have generally similar physicochemical properties, but differ in the presence of one or two chemical compounds characteristic of a given area. The use of local raw materials allows to reduce the cost of road construction by reducing transport costs. This is especially true for areas where there are no quarries for the extraction of stone materials suitable for use in the composition of asphalt concrete. In this regard, the study of the influence of the chemical composition of rocks on the aging process of bitumen is an urgent topic of research.

Bitumen for asphalt pavements does not always have the required parameters, such as adhesion, increased elasticity, resistance to aging, heat, workability of the mixture. To improve the quality properties of bitumen and asphalt concrete mixtures, additives and modifiers are used, for example: to increase elasticity, improve adhesion to mineral aggregates, reduce viscosity, increase resistance to the aging process, and prevent the binder from flowing off the aggregate surface. In some cases, the required properties can be changed by changing the properties of the mineral filler. [18-21]

Adhesion improvers are surfactants that lower the surface tension in the bitumen-aggregate phase and thus improve wetting. A number of scientific articles present the results of testing the use of additives and indicate their positive effect on the adhesion of bitumen to aggregate to acidic and neutral aggregates (granite, quartz). However, a number of researchers show that these additives also affect the basic properties of the bitumen binder, such as penetration, softening point, viscosity. [22, 23] In the production of low-temperature asphalt mixtures (WMA), organic compounds such as amide waxes are used as additives. mountain waxes, low Fischer-Tropsch (FT) paraffin wax, zeolites. Each of them has different characteristics, while others affect the asphalt production process. Waxes and paraffin's also affect the physical and mechanical properties of asphalt concrete, and zeolites improve the workability of the mixture. The type of additive should be chosen carefully so that the melting point of the additive is higher than the expected operating temperatures. This reduces the risk of permanent deformation and minimizes cracking of the asphalt at low temperatures. Surfactants reduce the surface tension when bitumen comes into contact with the aggregate and improve wetting. Modifiers, unlike additives, are part of the bitumen structure and create a three-dimensional network. Bitumen modified by the addition of high molecular weight substances, such as synthetic polymers, changes the thermo viscous and elastic-viscous properties of bitumen. The quality level depends on the type of modifier and its amount in the bitumen, the type of bitumen and chemical composition, as well as on the technology, mainly the homogenization method.

All of the above additives and techniques can improve the characteristics of asphalt concrete at the time of its production and the initial period of operation. Little attention is paid to such an indicator as thermal aging of bitumen, which determines the service life of asphalt concrete.

\section{Methods and materials}

At the Perm National Research Polytechnic University, at the Department of Roads and Bridges, together with the Perm Agrarian-Technological University, studies were carried out on the effect of the chemical composition of the mineral filler on the aging of bitumen. The following materials were used for the study: crushed stone of the Alapaevskoye deposit, the Khromisty open-pit mine; crushed stone of the Druzhininsky deposit, the Druzhininsky quarry; crushed stone of the Gusevogorsk deposit, open pit "KGOK". The chemical composition of crushed stone from different quarries is presented in Table 1. 
Table 1. Chemical composition of crushed stone from different quarries

\begin{tabular}{|l|c|c|c|}
\hline \multicolumn{1}{|c|}{ Mass fraction } & $\begin{array}{c}\text { Quarry } \\
\text { "Chromisty" }\end{array}$ & $\begin{array}{c}\text { Quarry } \\
\text { "Druzhininsky" }\end{array}$ & Open pit "KGOK" \\
\hline Calcium oxide, \% & 29,88 & 63,30 & 30,64 \\
\hline Magnesium oxide, \% & 11,58 & 10,32 & 12,58 \\
\hline Silicon dioxide, \% & 46,22 & 26,22 & 39,74 \\
\hline Sulfur, \% & - & 0,02 & 0,02 \\
\hline Phosphorus, \% & - & 0,03 & 0,02 \\
\hline Iron oxide, \% & 2,94 & 0,06 & 14,55 \\
\hline Aluminum oxide, $\%$ & 9,50 & 0,16 & - \\
\hline Manganese oxide, $\%$ & 0,06 & 0,02 & 0,14 \\
\hline $\mathrm{K}_{2} \mathrm{O}+\mathrm{Na}_{2} \mathrm{O}, \%$ & $0,28+4,94$ & $0,04+0,15$ & - \\
\hline $\mathrm{TiO}_{2} \%$ & 0,24 & 0,005 & 2,26 \\
\hline $\mathrm{CrO}_{5} \%$ & - & - & 0,05 \\
\hline
\end{tabular}

Crushed stone before mixing with bitumen was crushed to a fraction of $2.5-5.0 \mathrm{~mm}$. The research used bitumen BND 100/130 produced by PJSC "Lukoil". To determine the indicators of bitumen, the methodology GOST 18180 Petroleum bitumen was used. Method for determining the change in mass after heating. During the experiment, heated crushed stone and bitumen were mixed and kept in a heating cabinet. The crushed stone / bitumen ratio was 1/4. The study was carried out using the equipment: glass cups, type ЧБН in accordance with GOSТ 25336 with an outer diameter of $(100 \pm 1) \mathrm{mm}$; drying cabinet with a volume of $67 \mathrm{dm}^{3}$, equipped with a thermostat that maintains the temperature with a deviation of no more than $\pm 1{ }^{\circ} \mathrm{C}$, with a ventilation hole with a diameter of $10 \mathrm{~mm}$; metal sieve with mesh $\mathrm{N} 07$ in accordance with GOST 6613; glass thermometer technical performance $\mathrm{P}$ with a graduation value of $1{ }^{\circ} \mathrm{C}$, up to $200{ }^{\circ} \mathrm{C}$ in accordance with GOST 28498; desiccators according to GOST 25336; technical laboratory scales with a weighing error of no more than $0.01 \mathrm{~g}$.

\section{Results and discussion}

The data obtained on the study of the indicators of bitumen after aging and contact with mineral filler from different quarries are presented in Table 2.

Table 2. Indicators of bitumen after testing.

\begin{tabular}{|l|l|c|c|c|c|c|}
\hline \multicolumn{1}{|c|}{ Indicator } & $\begin{array}{c}\text { Initial } \\
\text { bitumen }\end{array}$ & $\begin{array}{c}\text { Initial } \\
\text { bitumen } \\
\text { after } \\
\text { testing }\end{array}$ & $\begin{array}{c}\text { Bitumen with } \\
\text { crushed stone } \\
\text { quarry } \\
\text { "Chromisty" }\end{array}$ & $\begin{array}{c}\text { Bitumen with } \\
\text { crushed stone } \\
\text { quarry } \\
\text { "Druzhininsky" }\end{array}$ & $\begin{array}{c}\text { Bitumen } \\
\text { with crushed } \\
\text { stone } \\
\text { "KGOK" }\end{array}$ \\
\hline 1 & KiSh & 46,8 & 52,8 & 52,5 & 52,5 & 51,7 \\
\hline 2 & $\begin{array}{l}\text { Depth of needle } \\
\text { penetration, at } 25^{\circ} \mathrm{C}\end{array}$ & 100 & 66 & 58 & 64 & 77 \\
\hline 3 & Penetration index & $-0,23$ & 0,09 & $-0,23$ & 0,02 & 0,33 \\
\hline 4 & Mass loss after testing & & 0,06 & 0,24 & 0,20 & 0,17 \\
\hline 5 & $\begin{array}{l}\text { Extensibility at } 25^{\circ} \\
\text { C, cm }\end{array}$ & 149,3 & 117,1 & 66,0 & 99,3 & 118,6 \\
\hline 6 & $\begin{array}{l}\text { Extensibility at } 0^{\circ} \mathrm{C}, \\
\mathrm{cm}\end{array}$ & 5,5 & 4,2 & 4,4 & 4,0 & 4,1 \\
\hline
\end{tabular}


Aging of bitumen can occur under the influence of many factors: temperature, light, chemical reactions. The process of bitumen aging itself can be represented as the transition of the constituent parts of bitumen from one form to another. Oils turn into resins, resins into asphaltenes. As a number of researchers show, the process of conversion of oils to resins is much slower than the conversion to asphaltenes. Over time, the asphaltene content increases in bitumen, which leads to the loss of such important properties of bitumen as extensibility and plasticity, while brittleness increases. Aging of bitumen causes irreversible structural changes in asphalt concrete, leading to the destruction of road surfaces. Asphalt concrete largely loses its ability to absorb tensile stresses. With a sharp drop in temperature in winter, the formation of cracks on the asphalt concrete pavement is observed and the process of destruction of the surface layer intensifies. Joint heating with mineral materials can increase the rate of bitumen aging. In this case, some mineral materials act as catalysts, in the presence of which the transition of the bitumen constituents occurs more intensively. Aging of bitumen-mineral mixtures can be divided into two periods. Until a certain time, the processes of aging of bitumen can be characterized only as processes of strengthening the structure of asphalt concrete, due to improved adhesion to the mineral surface (the acid number increases in bitumen), as a result of which the water resistance and frost resistance of asphalt concrete increases. An increase in the viscosity of bitumen during this period leads to an optimal increase in the strength and deformation resistance of asphalt concrete. Further, due to an increase in the brittleness of bitumen, adhesion decreases, leading to a decrease in the corrosion resistance of the road surface, and due to excessive rigidity, cracks appear in it more often.

\section{Conclusions}

Aging of bitumen and bitumen-mineral mixtures differs in the ratio of the duration of these periods. For the most resistant to aging bitumen, the first period lasts a long time, and is practically commensurate with the service life of asphalt concrete pavements. For coatings with bitumen that are not resistant to aging, after a year or two, a period of intense aging may occur, which is due to the presence of certain chemical elements. Additionally, it can be assumed that other chemical elements can, on the contrary, hinder the aging process of bitumen. The obtained research data show that the increase in the rate of aging of bitumen is influenced by the compounds of silicon and aluminum. On the other hand, metals such as iron and titanium contribute to the preservation of the initial plasticity of bitumen, and the accumulation of asphaltenes in the structure of the bitumen-mineral mixture slows down. In this regard, it can be concluded that when selecting materials for the design of an asphalt concrete mixture, it is necessary to take into account the chemical composition of rocks and their ability to influence not only the adhesion of bitumen, but also its ability to thermal aging upon direct contact of bitumen and mineral particles.

\section{References}

[1] Benosman A S, Senhadji Y, Mouli M 2015 Application of Polymer-Mortar Composites as a Sustainable Building Material Key Engineering Materials 650 21-28.

https://doi.org/10.4028/www.scientific.net/KEM.650.21

[2] Yang E H, Liu Y Q, Chen Z T 2015 Environmental Sustainability through Recycling Incineration Bottom Ash for the Production of Autoclaved Aerated Concrete Key Engineering Materials, 650 51-70. https://doi.org/10.4028/www.scientific.net/KEM.650.51

[3] Kannamma D, Meenatchi Sundaram A 2015 Implications of Building Material Choice on Outdoor Microclimate for Sustainable Built Environment Key Engineering Materials 650 82-90. https://doi.org/10.4028/www.scientific.net/KEM.650.82 
[4] Hussain A, Arif Kamal M 2015 Energy Efficient Sustainable Building Materials: An Overview Key Engineering Materials 650 38-50.

https://doi.org/10.4028/www.scientific.net/KEM.650.38

[5] Vaisman Y I, Pugin K G, Vlasov A S 2020 Using the Resource Potential of Drill Cuttings in Road Construction IOP Conference Series: Earth and Environmental Science 459(2) 022078. https://doi.org/10.1088/1755-1315/459/2/022078

[6] Xu, S.; Yu, J.; Zhang, C.; Sun, Y. Effect of ultraviolet aging on rheological properties of organic intercalated layered double hydroxides modified asphalt. Constr. Build. Mater. 2015, 75, 421-428. https://doi.org/10.1016/j.conbuildmat.2014.11.046

[7] Tyuryukhanov K Y, Pugin K G 2020 An Impact of Waste Foundry Sand on Asphalt Concrete Mixture IOP Conference Series: Materials Science and Engineering 753(2) 022079. https://doi.org/10.1088/1757-899X/753/2/022079

[8] Wu, S.; Zhao, Z.; Xiao, Y.; Yi, M.; Chen, Z.; Li, M. Evaluation of mechanical properties and aging index of 10-year field aged asphalt materials. Constr. Build. Mater. 2017, 155, 11581167. https://doi.org/10.1016/j.conbuildmat.2017.08.102

[9] Abu Qtaish, L.; Nazzal, M.D.; Abbas, A.; Kaya, S.; Akinbowale, S.; Arefin, M.S.; Kim, S.S. Micromechanical and chemical characterization of foamed warm-mix asphalt aging. J. Mater. Civ. Eng. 2018, 30, 04018213. https://doi.org/10.1061/(ASCE)MT.1943-5533.0002430

[10] Bowers, B.F.; Huang, B.; Shu, X.; Miller, B.C. Investigation of reclaimed asphalt pavement blending efficiency through GPC and FTIR. Constr. Build. Mater. 2014, 50, 517-523. https://doi.org/10.1016/j.conbuildmat.2013.10.003

[11] Pugin K G 2020 Influence of quality indicators of the surface of mineral particles on the properties of asphalt concrete IOP Conference Series: Materials Science and Engineering 971(3) 032043. https://doi.org/10.1088/1757-899X/971/3/032043

[12] Lee, S.J.; Hu, J.; Kim, H.; Amirkhanian, S.N.; Jeong, K.D. Aging analysis of rubberized asphalt binders and mixes using gel permeation chromatography. Constr. Build. Mater. 2011, 25, 1485-1490. https://doi.org/10.1016/j.conbuildmat.2010.08.004

[13] Wang, P.Y.; Zhao, K.; Glover, C.; Chen, L.; Wen, Y.; Chong, D.; Hu, C. Effects of aging on the properties of asphalt at the nanoscale. Constr. Build. Mater. 2015, 80, 244-254. https://doi.org/10.1016/j.conbuildmat.2015.01.059

[14] Chen, A.; Liu, G.; Zhao, Y.; Li, J.; Pan, Y.; Zhou, J. Research on the aging and rejuvenation mechanisms of asphalt using atomic force microscopy. Constr. Build. Mater. 2018, 167, 177184. https://doi.org/10.1016/j.conbuildmat.2018.02.008

[15] Zhang, D.; Zhang, H.; Shi, C. Investigation of aging performance of SBS modified asphalt with various aging methods. Constr. Build. Mater. 2017, 145, 445-451.

https://doi.org/10.1016/j.conbuildmat.2017.04.055

[16] Yu, J.; Dai, Z.; Shen, J.; Zhu, H.; Shi, P. Aging of asphalt binders from weathered asphalt mixtures compared with a SHRP process. Constr. Build. Mater. 2018, 160, 475-486. https://doi.org/10.1016/j.conbuildmat.2017.11.060

[17] Yan, C.; Huang, W.; Tang, N. Evaluation of the temperature effect on Rolling Thin Film Oven aging for polymer modified asphalt. Constr. Build. Mater. 2017, 137, 485-493. https://doi.org/10.1016/j.conbuildmat.2017.01.135 
[18] Dondi, G.; Mazzotta, F.; Simone, A.; Vignali, V.; Sangiorgi, C.; Lantieri, C. Evaluation of different short term aging procedures with neat, warm and modified binders. Constr. Build.

Mater. 2016, 106, 282-289. https://doi.org/10.1016/j.conbuildmat.2015.12.122

[19] Xu S., Fan Y., Feng Z., Ke Y., Zhang C., Huang H. Comparison of quantitative determination for SBS content in SBS modified asphalt Construction and Building Materials, Volume 282, 2021. https://doi.org/10.1016/j.conbuildmat.2021.122733

[20] Chomicz-Kowalska, A., Mrugala, J., Maciejewski, K.: Evaluation of Foaming Performance of Bitumen Modified with the Addition of Surface Active Agent, WMCAUS, 245 (2017), pp.111. https://doi.org/10.1088/1757-899X/245/3/032086

[21] 21.Iwanski, M., Chomicz-Kowalska, A., Maciejewski, K.: Application of synthetic wax for improvement of foamed bitumen parameters, Construction and Building Materials 83 (2015), pp.62-69, 2015. https://doi.org/10.1016/j.conbuildmat.2015.02.060

[22] A. Vaitkus, D. Cygas, A. Laurinavicius, Z. Perveneckas, Warm mix asphalt research, analysis and evaluation, The Baltic Journal of Road and Bridge Engineering, 4 (2), 2009, pp. 8086. https://doi.org/10.3846/1822-427X.2009.4.80-86

[23] P. Radziszewski, K. Kowalski, J. Król, M. Sarnowski, J. Piłat: Quality assessment of bituminous binders based on the viscoelastic properties: polish experience.Journal of Civil Engineering and Management, vol. 1(20), 2014, pp. 111-120.

https://doi.org/10.3846/13923730.2013.843586 